\title{
Anna Matuchniak-Mystkowska*
}

iD https://orcid.org/0000-0001-5172-3637

\section{PRISONER-OF-WAR STORIES IN THE MOVIES (THE CASE OF ANDRZEJ MUNK'S EROICA)}

\begin{abstract}
This paper analyses Polish feature films which deal with the subject of POW camps during World War II, especially the so-called oflags (German: Offizierslager), i.e. Wehrmacht camps for officers. In Poland, nearly 200 feature films about World War II and the Nazi occupation were made in 1945-1999, with only eight raising the topic of POW camps. Eroica directed by Andrzej Munk is one of the first examples, and the best-known one. It depicts the social world of the oflags in a grotesque and ironic light, which was acclaimed by film experts but criticised by historians. The theoretical and methodological approach used in the sociology of art and in historical sociology can be invoked to analyse all the elements of the communication system: the creator, the work, and the audience in their social and historical context. The sociological analysis presented here only concerns the content of the film (the juxtaposition of "the truth of time" and "the truth of the screen") and its social reception among different categories of viewers, each with their specific competences. The theoretical concepts developed by S. Ossowski, A. Kłoskowska, P. Francastel, E. Panofsky and P. Bourdieu are used here, alongside historical and sociological analyses of POW camps (D. Kisielewicz, A. Matuchniak-Mystkowska). The paper presents a certain research idea and describes methods that can be used to pursue it.
\end{abstract}

Keywords: Eroica, Polish film, film reception, World War II, prisoners of war, oflags, historical sociology, sociology of film, sociology of art.

\section{Polish films about World War II}

This paper analyses Polish feature films dealing with the subject of prisoner-ofwar (POW) camps during World War II, especially oflags (German: Offizierslager), i.e. Wehrmacht camps for officers.

In view of their visual and verbal form, both feature films and documentaries which are in mass circulation in the cinema or television have considerable potential for social impact, as they combine informational and entertainment roles in a way typical of the "third cultural system" (Antonina Kłoskowska’s theoretical

* Prof. zw. dr hab., Sociology of Art and Education Department, Faculty of Economic and Sociology, University of Lodz, ul. Rewolucji 1905 r. 41/43, 90-214, Łódź, Poland, e-mail: anna. matuchniak@wp.pl 
approach) (Kłoskowska 1972; 1983). In Poland, over 200 cinematic films about World War II have been produced, and the number of television films is at least as high. In 1945-1999, a total of 197 feature films about World War II and the Nazi occupation were made, with only eight dealing with the subject of POW camps (Steyer 2013). The following titles are worth mentioning in this context: Ostatni etap [The Last Stage] (1948, directed by W. Jakubowska), Eroica (1957, directed by A. Munk), Pasażerka [Passenger] (1963, directed by A. Munk), Kornblumenblau (1989, directed by L. Wosiewicz), Cynga (1991, directed by L. Wosiewicz - a film about gulags), Życie za życie [Life for Life] (1991, directed by K. Zanussi - a biography of M. Kolbe), Twarz anioła [Angel's Face] (1971, directed by Z. Chmielewski - a film about a children's camp in Łódź), or Krajobraz po bitwie [Landscape after a Battle] (1970, directed by A. Wajda). In 2000-2017, a total of 26 feature films about World War II were shot and released in cinemas, but only a few of this number were devoted strictly to POW-related themes: Katyń [Katyn] (2007, directed by A. Wajda) or Pianista [The Pianist] (2002, directed by R. Polanski). Some films dealt directly with the war while others included war scenes in dialogues and images, but the film was set in contemporary times, and the war was an important private drama experienced by the protagonists (one can trace post-memory themes there) (Matuchniak-Mystkowska 2017). The renowned contemporary TV series about World War II, made under the auspices of Polish television and well-known to the general public (with multiple re-runs) include: Boża podszewka [God's Lining] (directed by I. Cywińska, two parts, 31 episodes, years of production: 1997 and 2005), Czas honoru [Time of Honour] (90 episodes in total, years of production: 2008-2014) (cf. Matuchniak-Mystkowska 2017; Wejbert-Wąsiewicz 2017a: 17-46; Wejbert-Wąsiewicz 2017b, an unpublished report).

Cinema attendance is a good indicator of the social impact of films. Out of the 20 most-watched films in Poland after 2014, eight were Polish films, and three of this group concerned various WWII events: Miasto'44 [City'44] (2014, directed by J. Komasa, almost 2 million viewers), Kamienie na szaniec [Stones for the Rampart] (2014, directed by R. Gliński, almost 1 million viewers), Powstanie Warszawskie [Warsaw Uprising] (2014, directed by J. Komasa, almost 600,000 viewers).

Thus, an average of three films about World War II were produced each year in post-war Poland between 1945 and 2017. An analysis of their content and form, as well as their social presence and reception in the light of film studies and sociology goes beyond the framework of this study. Even an analysis of only one film must necessarily be selective.

One of the most famous films on POW themes is Eroica. Symfonia bohaterska $w$ dwóch częściach (Scherzo alla polacca, Ostinato lugubre) [Eroica. A Heroic Symphony in Two Movements (Scherzo alla polacca, Ostinato lugubre)] by Andrzej Munk, made in 1957 and based on a short story by Jerzy Stefan Stawiński (music: Jan Krenz, cinematographer: Jerzy Wójcik). The film had its premiere on 4 January 1958. The title of the film invokes Symphony No. 3 in EFlat Major - Eroica by 
Ludwig van Beethoven, dedicated to Napoleon and addressing the issue of heroism. To invoke Mieczysław Wallis's semiotic analysis of the titles of works of art, we should note not only the identifying function of the title, signifying a specific work of art, but also the author's semantic suggestion implying a poetic character of the work (Wallis 1983). The use of the term "symphony" in relation to a film is an example of synaesthesia, i.e. references to various senses, associations and experiences. According to some critical analyses by film experts, this work, classified as belonging to the so-called "Polish film school", initiated the ironic-grotesque current within that school. In his film, Andrzej Munk challenges the stereotype of a Polish national hero. In the first part, almost comedy-like, he addresses the stereotype of the Warsaw Uprising and the heroic insurgent (an excellent performance by Edward Dziewoński). In the second part, more serious, the film addresses the stereotype of Polish officers in German captivity. According to the author and some critics, "Although the film shows heroism in a completely non-stereotypical way, this is not an anti-heroic film. Eroica does not speak ill of the protagonists, even if their deeds are irrational; the protagonists are always shown with liking and fondness. We have only shown that this type of manifestation is useless in specific situations". The creators' intention was to show ordinary people, loyal to their group, capable of sacrifices for others and the common good. The film received several national and international awards and became part of the Polish cinematic canon. However, critics' and viewers' opinions have been divided for many years, for ideological rather than aesthetic reasons. While the artistic value of the film was widely acknowledged, the fact that the cult of national heroes was being undermined aroused widespread resentment (although, incidentally, this approach was in line with the communist ideology). Sociological research on the reception of this film leads to similar conclusions, and the director's vision created at the time did not meet with an unambiguously positive response from his contemporaries (which will be discussed further).

In his book entitled II wojna światowa w polskim filmie. Historia a fabula [World War II in Polish Film. History and the Plot], Krzysztof Steyer describes Munk's Eroica, drawing attention to the excellent cast and content of the film. His concise description is worth quoting. "Part two, Ostinato lugubre (steadily gloomy), based on the short story called Escape, is set in a POW camp for officers. Actors in this part include: Kazimierz Rudzki (Second Lieutenant Turek), Józef Nowak (Second Lieutenant Kurzawa), Henryk Bąk (Lieutenant Krygier), Mariusz Dmochowski (Lieutenant Korwin-Makowski), Roman Kłosowski (Second Lieutenant Szpakowski), Bogusław Kobiela (Lieutenant Dąbecki), Józef Kotecki (Lieutenant Żak), Tadeusz Łomnicki (Lieutenant Zawistowski), Wojciech Siemion (Lieutenant Marianek), and Ignacy Machowski (Major Grzmot). Here, we observe the community in the camp, with officers psychologically tired of one another as a result of long-term incarceration. The community's spirits are raised by the myth of Lieutenant Zawistowski's successful escape from the camp. Only a few people know that the escape is fictitious and the alleged hero is hiding in 
the attic of a camp barrack, in ill health. Critics emphasise that the cast was aptly selected in both the first and the second part of the film. Special attention should be paid to the role of Kazimierz Rudzki, who himself had been a prisoner of war in the Woldenberg C camp" (Steyer 2013: 25).

In the introduction to the chapter entitled Polish Film School 1955-1960, K. Steyer lists renowned film directors (A. Wajda, A. Munk, T. Konwicki, W.J. Has), screenwriters (Jerzy Stefan Stawiński), cinematographers (Jerzy Wójcik, Jerzy Lipman, Jan Laskowski, Kurt Weber), and actors (Zbigniew Cybulski, Bogumił Kobiela, Tadeusz Janczar, Adam Pawlikowski). He claims that the most outstanding films of this period were: Kanat [Canal] (1957), Popiót i diament [Ashes and Diamonds] (1958), Lotna [Lotna] (1959) by Andrzej Wajda, Eroica [Eroica] (1957), Zezowate szczęście [Bad Luck] (1959) by Andrzej Munk, Ostatni dzień lata [The Last Day of Summer] (1958), Zaduszki [All Souls'Day] (1961) by Tadeusz Konwicki, Krzyż walecznych [Cross of Valour] (1958), Nikt nie woła [Nobody's Calling] (1960) by Kazimierz Kutz, Pożegnanie [Farewell] (1958) and Jak być kochana [How to Be Loved] (1962) by Wojciech J. Has. He invokes the opinions of film critics and theorists, including Marek Hendrykowski and Aleksander Jackiewicz, and emphasises technical mastery and artistic solutions, as well as historical interests (Hendrykowski 2011a; 2011b). The political context, i.e. the "thaw" after Stalin's death in 1953 and the abolition of the "cult of personality" in 1956, enabled filmmakers to tackle the period of World War II and human fates. It was supposed to be "a great historical, social and moral treatise in the context of the life around us and our time" (Steyer 2013: 19).

In Piotr Kurpiewski's book Historia na ekranie Polski Ludowej [History on the Screen in People's Republic of Poland], which contains an interesting review of Polish cinematography, Munk's Eroica is neither singled out nor discussed. It is merely mentioned in two excerpts of this extensive book. The author showed surprisingly little interest in this cinematic work. In the introductory remarks, the book quotes Bolesław Michałek's opinion that two Munk's films, i.e. Eroica and Zezowate szczęście [Bad Luck], are rare examples of the ludic model in historical cinematography (Kurpiewski 2017: 17). In my view, one cannot agree with this assessment of the second "movement" of Symfonia bohaterska - Ostinato lugubre [Heroic Symphony: Ostinato lugubre]. Eroica is mentioned again when discussing Wajda's Popioty [Ashes] in the context of the historian Zbigniew Załuski's criticism of film mythology which does not correspond with reality (Kurpiewski 2017: 113). Thus, it is legitimate to juxtapose "the truth of time" and "the truth of the screen".

\section{Historical facts: The truth of time}

In 1939-1945, there were approx. 800 camps in 20 German military districts for approx. 10 million POWs of several dozen nationalities, including almost 0.5 million Poles (Kobylarz, Sznotala 2010). During the defensive war of 1939, a total of 
20,000 Polish officers were taken prisoner by the Germans, while others followed their fate after the takeover of interned personnel from Romania and Hungary, and after the fall of the Warsaw Uprising. In 1939, the Germans set up 23 camps for POWs on Poland's territory, adding six in the following years, following which they resettled and "shuffled" Polish POWs among them. In 1944, Polish officers and some soldiers were grouped in four camps: Oflag II C in Woldenberg (the current name of the village is Dobiegniew), Oflag II D Gross Born (currently: Borne Sulinowo in the Szczecin region), Oflag VI B Dössel (Munster region) and Oflag VII A Murnau (Munich region). Roman numerals denote the military districts of the German Reich where the camps were located, while the letters of the alphabet signify the order in which they were established (Matuchniak-Krasuska 2014).

Eroica. Ostinato lugubre shows Oflag VII A Murnau and presents a story that happened in reality, although the cinematic version differs from the real events in many details (Kisielewicz 2015).

Oflag VII A Murnau, located in Bavaria at the foot of the Alps, was the so-called Musterlager - an exemplary camp shown to visiting institutions such as the International Committee of the Red Cross in Geneva. It existed from September 1939 to April 1945. The number of prisoners ranged from about 4,000 in 1941 to almost 5,000 in January 1945 and exceeded the "density standards" for German soldiers by a factor of six.

The camp was located in barracks built by the Wehrmacht before the war. The area of about 8 ha, surrounded by barbed wire and guard towers, comprised a number of buildings: 3 storey barracks, an administrative utility building, a sports hall, a sports field, 8 garages, a fire pool, POW gardens, a roll-call square also used as a "walking yard". Barracks A, B and C were inhabited by senior officers and disabled POWs (about 3,000), the 5 garage buildings (E, F, G, J and K) were inhabited by junior officers (about 1,000 ), garage $\mathrm{H}$ was inhabited by privates (300 orderlies), building L (back-up) was a sports training room, and building D was used for the theatre. The camp also housed the German headquarters (NKO), the sick bay and servicing workshops. The living conditions were better than in other camps, e.g. in Oflag II C Woldenberg or Oflag II D Gross Born, where everyone lived in barracks, although all were overcrowded. The attics of the buildings did not have enough daylight or thermal fittings: it was very cold in winter and overly hot in summer. The garages were dark, damp and cold (winter temperatures reached $7-13^{\circ} \mathrm{C}$ ).

The prisoners were locked inside from 10 p.m. to 6 a.m., and sometimes much earlier as a form of punishment. Not only the doors but also the windows had to be closed and darkened. Routine morning and evening roll-calls (9 a.m. and 6 p.m.) lasted 45 minutes, but when the roll-calls played a punishing role, POWs had to stand outside on the square for many hours.

The food, nicknamed "Kraut food", was supposed to provide each prisoner with 1,700 kcal per day, but in fact it only provided half as much, and the food was of poor quality. POWs who received no parcels from home or from aid organisations (Red Cross, YMCA) for three months faced illnesses and/or starving to death. 
An oflag resembled a small town with service outlets (hairdresser, tailor, doctor), religious, cultural, educational and artistic activities (theatre, concerts, fine arts), as well as sports. Culture helped the inmates to maintain morale, spend time sensibly, and survive captivity in a better mental and physical condition.

The realities of POW camps have been described by historians in books and articles, either monographic or focused on specific issues. The most important source that can be instrumental in assessing the "realism" of Eroica is the monograph by Danuta Kisielewicz entitled Niewola w cieniu Alp. Oflag VII A Murnau [Captivity in the Shadow of the Alps. Oflag VII A Murnau], focused on this particular POW camp (Kisielewicz 2015). Other publications that can prove helpful in assessing "the truth of the screen" include excellent thematic studies focused on Polish POWs in German captivity, including the distribution of parcels, academic and educational activities, religious life, physical education and sport (Kisielewicz 1998; Pollack 1986; Olesik 1988; Bednorz 1989; Rezler-Wasielewska 2001; Półchłopek 2002; Honka 1998; Bohatkiewicz 1971; Giziński, Szutowicz 2013).

The numerous memoirs and abundant biographical literature written by the participants in World War II (Polish soldiers and officers), in the form of diaries and memoirs written in POW camps, as well as memoirs edited after the war, either from memory or on the basis of their own notes, have both documentary and literary value (Brandys 1955; Lewicki 2007; Fularski 2009). Particularly noteworthy are the memoirs of officers who were kept as POWs in Oflag VII A Murnau: F. Brzezicki, J. Neterowicz, T. Gruszka, W. Iwanowski, S. Majchrowski, J. Rowiński, J. Lewandowski, M. Siarkiewicz and P. Wiktorski (Brzezicki 2013; Neterowicz 2015; Gruszka 1994; Iwanowski 1981; Majchrowski 1970; Rowiński 2016; Lewandowski 2016; Siarkiewicz 1998; Wiktorski 1980).

The screenplay of Andrzej Munk's Eroica was based primarily on fiction: short stories by Jerzy Stefan Stawiński, as well as selected works by Melchior Wańkowicz (Stawiński 1984; Wańkowicz 1955; 1969).

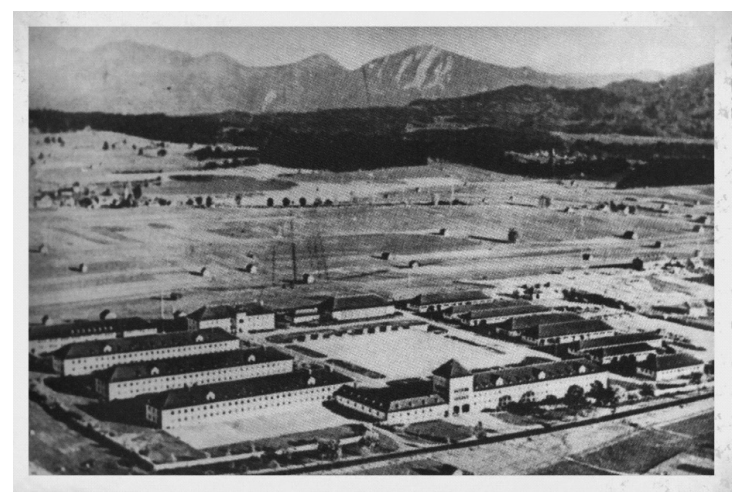

Photo 1. Oflag VII A Murnau

Source: Collection of the Central Museum of Prisoners of War (CMJW) in Opole. 


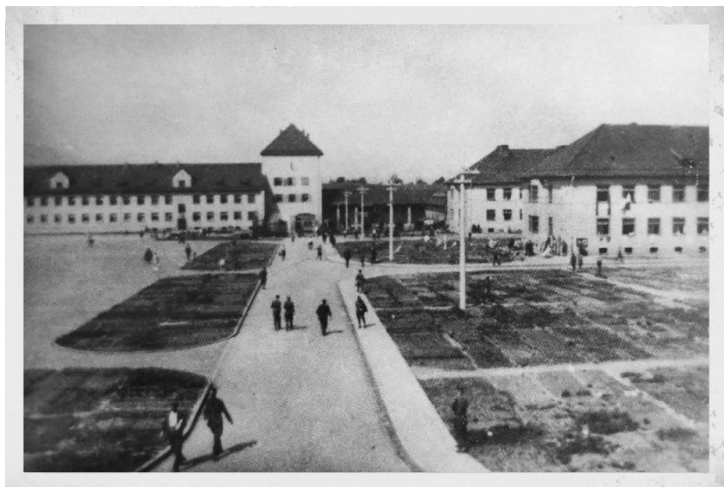

Photo 2. Oflag VII A Murnau - opposite: the building of the German commanders, on the right: blocks A and B

Source: Collection of the Central Museum of Prisoners of War (CMJW) in Opole.

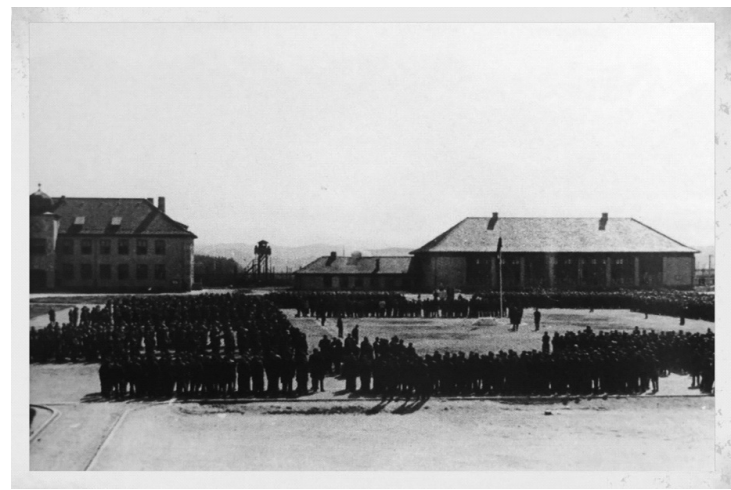

Photo 3. A roll-call in the camp

Source: Collection of the Central Museum of Prisoners of War (CMJW) in Opole.

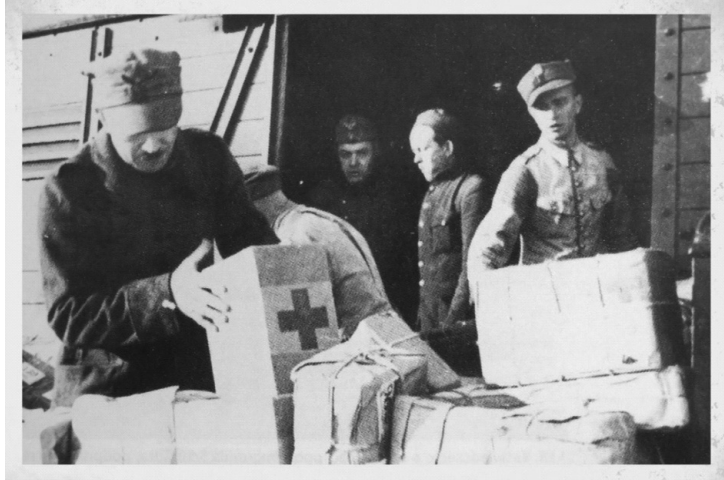

Photo 4. Parcels being unloaded

Source: Collection of the Central Museum of Prisoners of War (CMJW) in Opole. 


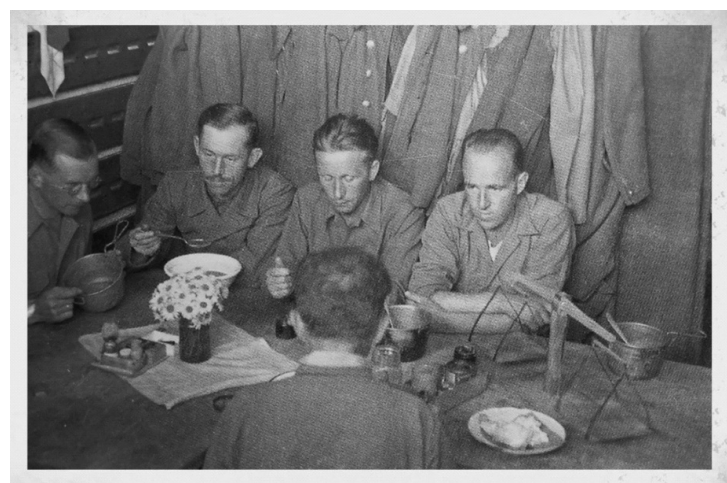

Photo 5. POWs eating a meal; right: primitive scales to measure food rations Source: Collection of the Central Museum of Prisoners of War (CMJW) in Opole.

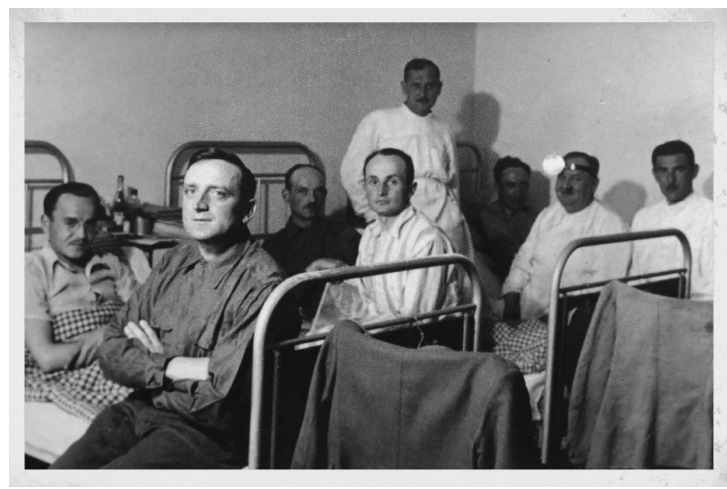

Photo 6. Polish doctors and medics in the field hospital

Source: Collection of the Central Museum of Prisoners of War (CMJW) in Opole.

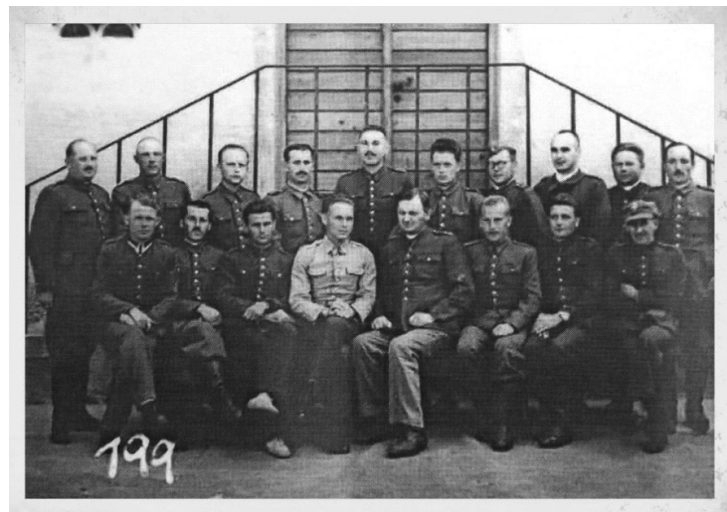

Photo 7. A memorial photograph of 70th Infantry Regiment officers from Pleszew, POWs in Oflag VII A Murnau (sitting 6th from the left: Lieutenant M. Siarkiewicz, 8th from the left: Lieutenant J. Rowiński; standing 5th from the left: Lieutenant J. Lewandowski) Source: Collection of the Central Museum of Prisoners of War (CMJW) in Opole. 
Sociological studies on this topic are scarce. This text is a contribution towards efforts aimed at juxtaposing the artistic truth, the biographical truth and the historical truth (Matuchniak-Krasuska 2014; 2016; Matuchniak-Mystkowska, Mystkowski, Stanek 2018).

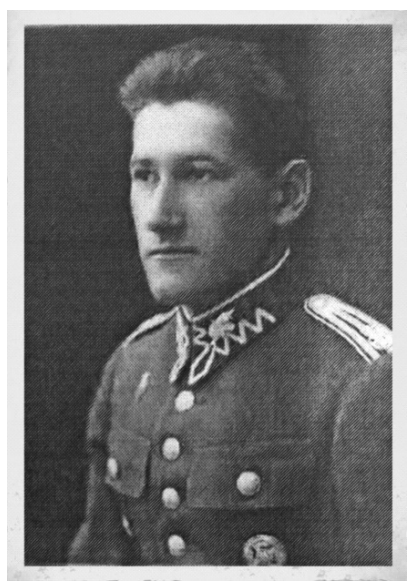

Photo 8. Lieutenant Julian Rowiński

Source: "Łambinowicki Rocznik Muzealny” 2016, no. 39.

\section{On the sociological analysis of films}

The sociology of art deals with the work of art as a message and a carrier of artistic values (the sociological aesthetics current), the artist situated in time and social space (the sociogenetic approach) and the recipients and social circulation of the work (the functional approach) (Matuchniak-Krasuska 1999). These approaches can be applied to any work of art from any field of art. Film is a visual art with verbal and audio elements, and the concept that is particularly useful when analysing films is that of realism. This is captured by the well-known phrase "the truth of time, the truth of the screen".

"The truth of the screen" can be captured by analysing the form and content of the cinematic work and its artistic value (beauty and other aesthetic aspects, originality) as well as the emotive value (expression, impression). Both cinematologists and sociologists can draw on developments in semiology, which reveal the multiplicity of codes in works of art, especially verbal and visual ones. Numerous publications devoted to images (in the broad sense of the word) draw attention to the mutual relations between verbal and visual codes, implying that they might be either independent, mutually interfering, superior and/or subordinated. The original approach was the "pan-linguistic" one, suggesting the superiority of words over images, and the domination of linguistic codes over iconic codes. Nowadays, many authors put a clear emphasis on the rich layer of image-based communication, although 
various researchers, including Yveline Baticle, note that compared to verbal codes, iconic codes are weaker and impermanent, which is related to the complexity of the context of iconic syntagm and the absence of discrete variables (e.g. a comparison between phonemes and chromatic continuum) (Baticle 1985). The symbolism of colours entails overlapping codifications. The verbal code is only one of the 25 codes that are used to analyse visual messages. Semioticians (e.g. R. Barthes, Ch. Metz, Y. Baticle) distinguish two categories of iconic codes: denotative (perceptive) and connotative. The former category includes: carrier code, transmission code, perspective code, morphological code (location, axes and lines of the image), typographic, topological, onomastic, linguistic, chromatic, and photographic codes (granularity, framing, tricks, density), cinematographic code (plans, shots, camera movement, sequences), and cinematic code (genres, styles). The latter category includes: recognition code, iconographic code, ambient code, tonality code, stylistic code, socio-cultural connotations, historical code, costumes, socio-political aspects, interpretation, gestures, psychological code and rhetorical code (B aticle 1985: 35-60; see also Matuchniak-Krasuska 2001: 53-81). Understandably, it is too difficult to take all these codes and levels of analysis into account, even in relation to a single film since this task would be too extensive. When writing about the aesthetics of cinema, Dominique Chateau uses the categories of work of art, beauty, aesthetic values, modernity, realism, taste, attitudes and aesthetic experiences (Chateau 2006).

Although the formal analysis of films is the domain of cinematologists, their analytical categories are used by sociologists who engage in theoretical deliberations and conduct empirical research, because the methodology of the social sciences is better suited to describe the social circulation of cinematographic works. In Ewelina Wejbert-Wąsiewicz's monograph, ten categories concerning the construction of a film and its social context turned out to be useful: film editing, colour, symbols, narration, frames, music, cast, the attitudes of film critics, popular reception and circulation (wide, narrow, cinema theatres, television) (Wejbert-Wąsiewicz 2017).

"The truth of time" can refer to three different moments in time: the story shown on the screen, the period during which the film was made, and the period during which it is received by the audience. Sociological research reveals the differences between these contexts and internal diversities in each of them (especially the diverse non-expert reception depending on the level of competence). The typology of realism contained in Stanisław Ossowski's work U podstaw estetyki [The Basis of Aesthetics] provides useful analytical tools (realism of content, realism of form) (Ossowski 1966). Erwin Panofsky's concept of three layers in a work of art and three levels of content analysis, i.e. preiconographic (object-based), iconographic (cultural content) and iconological (philosophical and ideological meanings), also enables precise analyses to be carried out (Panofsky 1971).

Stanisław Ossowski argued that realism can be attributed to a work of art because of its relation to the presented object (realism of performance: how), or 
because of the relation of the presented object to objective reality (realism of content: what is presented). Realism of content is divided into individual realism, showing a specific referent (portrait, chronicle, biographical novel), and generic realism, consisting in recreating what is typical and important, as well as the realism of specific components (e.g. Michelangelo used anatomical realism in combination with unnatural poses). Realism of performance includes: illusionism, hierarchical realism according to objective norms, subjective realism, and psychological realism (Ossowski 1966).

We will attempt to use these concepts to analyse "the truth of time and the truth of the screen" with reference to Andrzej Munk's Eroica.

The film employs individual realism because the protagonist, Lieutenant Zawistowski, is really Captain Edward Mamunow, a "double POW" hiding in Oflag VII A Murnau from July 1940 to May 1941. As rumours of his successful escape were spread, this helped to "lift spirits" among the POWs. Described below is his story during the war, and the real reasons for his hiding in the oflag, which were personal rather than pro-social. Captain E. Mamunow, an officer of the 70th Infantry Regiment from Pleszew, took part in the September 1939 campaign in the battle of Bzura. He executed three German prisoners of war who were guilty of massacring the entire population of a village. Taken into German captivity, he was sentenced to death and put under arrest in that oflag. After a successful escape, he found a hiding place in the camp with the help of his mates. A few people helped him, but approximately 30 people were aware of his situation. The case ended tragically: the character in the film fell ill and died; the real one committed suicide in order not to reveal the secret and to avoid turning in the friends who had helped him. When a fire, triggered by a primitive stove, broke out in his hideout, Mamunow tried to avoid being burned alive and hung himself on the strings which were used to pull food and water into his hideout in the attic. He had vowed that he would not be taken alive by the Germans (and he managed to achieve this) (Lewandowska-Pijanowska, Rezler-Wasielewska 2016).

Individual realism is also epitomised by other film characters: the mates helping Mamunow in hiding, and those initiated into the matter (the number of the latter is smaller in the film, which is an example of generic realism). The most important figure is Second Lieutenant Turek, played by Kazimierz Rudzki, an officer and POW at Oflag II C Woldenberg, who himself had been in German captivity for over five years, from autumn 1939 to spring 1945. Rudzki was the only member of the film crew who knew the camp reality from personal experience. Lieutenant Kurzawa, played by Józef Nowak, was sent to an oflag after the Warsaw Uprising and personifies this category of POW. It is worth adding that he is the alter ego of J.S. Stawiński, the author of the short story called Ucieczka [Escape] on which the screenplay was based. The "old POWs" (those from 1939) and the "new ones" (from 1944) represented two completely different social worlds in view of their military biographies (regular professional army and reservists versus underground 
army and partisans) and the time spent in German captivity "behind the wires". The film aptly presents this issue by using generic and individual realism. Generic, individual and psychological realisms are combined to present different types of people, especially old POWs from the September Campaign and new POWs from the times of the Warsaw Uprising. In the oflag reality, the helpers who were initiated in the matter were: Lieutenant Julian Rowiński, Lieutenant Jan Lewandowski, and Lieutenant Marian Siarkiewicz. Their memories, used by J. S. Stawiński and M. Wańkowicz in their writing, are slightly different. Quite understandably, a film protagonist is sometimes a "concoction" of several real characters, and his story draws on events that happened to a few different people in different places and at different times. Thus, "the truth of the screen" is a collection of real situations while the protagonist is a hybrid creation (Matuchniak-Krasuska 1999). Generic realism prevails over individual realism.

Generic and individual realism can also be noticed in the film set, which corresponds exactly to Oflag VII A Murnau, but also to other oflags, all of which were built according to a single urbanistic pattern. This statement also applies to the camp architecture (barbed wires, guard towers, main square, barracks), the interiors and furnishings of the POW hall (building handy details such as a booth serving as a surgery, a curtain around the bed, or food scales), and the organisation of camp life (roll-calls, POW activities, parcel reception, food distribution, escapes, workshops).

The eminent French sociologist Pierre Francastel proposed conducting comparative studies of signs and symbols indicating the homology of different symbolic systems: science, religion, and art, including different fields of art (Francastel 1984). It is therefore justified to juxtapose the history of the oflags and the fates of prisoners of war, as shown in various works of art and the media: historical, sociological, biographical studies (such as diaries, memoirs, recollections of prisoners of war); museums and memorial sites. Many literary and poetic works and fine arts (drawings, graphics, painting), as well as visual works (photographs, films) have been inspired by the topic of oflags. The photographs presented here illustrate the time and locale and can be found in various frames of the film. The most popular book containing oflag memoirs is Wyprawa do oflagu [The Expedition to an Oflag] by Marian Brandys, an officer and prisoner of Oflag II C Woldenberg. Published in 1955, much like Munk's Eroica, it shows the reality of the camp in a realistic way in the iconographic layer and in an ironic and mocking way in the iconologic layer. A sociogenetic analysis helps to demonstrate that these are compatible examples of literature and films, in line with the communist atmosphere and censorship. While it is impossible to persuade the reader of this paper to engage in an actualising reception of these works, one can quote the only poem describing the tragic story of Captain Edward Mamunow, written by Lieutenant J. Lewandowski, whose memories were used by J. S. Stawiński when writing the screenplay. Both the memoirs and the poem show the truth of the war time and are free from the stigma of communism. 
Bohater zawisł na sznurku przyjaźni

Stopy przebiły gładź sufitu - strychu

Dając ujście dymu z miejsca kaźni

I zamierzoną śmierć bez zaszczytu.....

Już go niosą na marach....

Tysiąc oczu pożera martwą sylwetkę

Oddając hołd majestatowi śmierci.

Diemerty, Freisingery, Oleszki - „knechty”

Ryczą na placu: „Gdzie są ci zbrodniarze,

Co pomagali - co mu siebie dali w darze

I przez tyle miesięcy uśpili wachty".

Biało-czerwona Murnau ziemia

Wchłonęła ciało jego w prochy....

Melchior, Munk głoszą pienia

Na cześć jego i towarzyszy dają strofy...

The hero has hung from a string of friendship

His feet have pierced the smooth ceiling - the attic

Giving an outlet for the smoke from the place of death

And an intended death without honours...

He is being carried on a stretcher...

A thousand eyes devouring a dead body

Paying homage to the majesty of death.

Diemerts, Freisingers, Oleszeks, the servants

Roaring in the yard: "Where are those criminals,

Who were helping him, who gave themselves to him as a gift

Dulling the guards' vigilance for so many months".

The white and red soil of Murnau

Absorbed his body into the ashes...

Melchior, Munk are chanting

With stanzas to honour him and his companions...

(Lewandowska-Pijanowska, Rezler-Wasielewska 2016: 39, 175). ${ }^{1}$

The problem of the same themes/content shown in different artistic disciplines contributes to a better understanding of "the truth of the screen".

1 Translation of a poem from Polish into English by Danuta Przepiórkowska. 


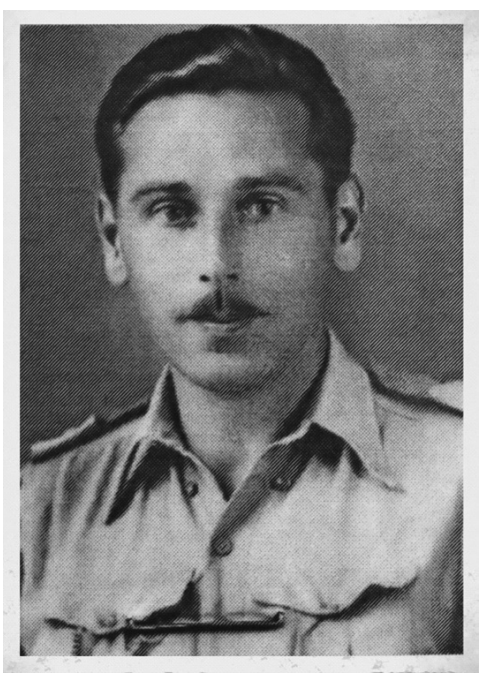

Photo 9. Lieutenant Jan Lewandowski

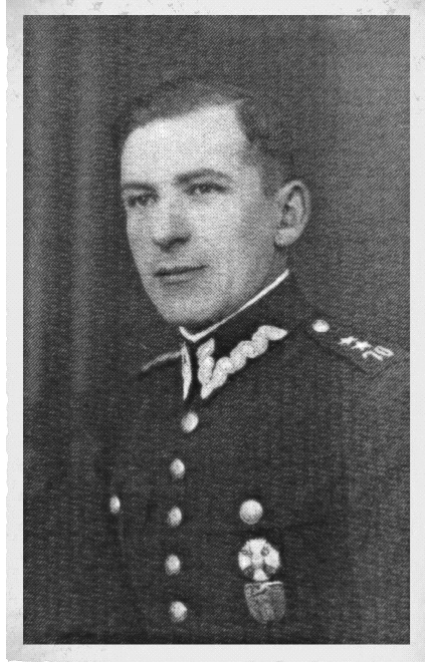

Photo 10. Captain Edmund Mamunow

Source: Photos 9 and 10: "Łambinowicki Rocznik Muzealny" 2016, no. 39.

\section{The sociological analysis of film reception}

Audiences are varied in terms of socio-demographic criteria, with the level and type of education being the most important, as demonstrated by all empirical studies (Kłoskowska, Rokuszewska-Pawełek 1990; Sułkowski 1972; 1996; Matuchniak-Krasuska 1988; 1999; Zimnica-Kuzioła 2003; Wejbert-Wąsiewicz 2017; Ethis 2011).

Formulated by the eminent French sociologist Pierre Bourdieu, the concept of artistic competence, which combines knowledge of art and the ability to apply it in practice to new, unknown works, is instrumental in providing a more accurate audience profile and perceptual procedures, going beyond the classification approach based on socio-demographic variables (Matuchniak-Krasuska 2010). It is important to recognise the context in which a work of art is being analysed, since it is situated either within in the universe of art (the viewer knows and recognises styles, conventions, forms, symbolism) or in the universe of life (the viewer concentrates on content). Since art is a sphere of freedom, and works of art are open to different kinds of perceptions by various viewers, both perceptual strategies are legitimate, and both do occur in practice.

Taking numerous sociological studies of the reception of art as a starting point, we can formulate a claim that artistic competence and life competence (or, rather contextual competence) are mutually complementary. Art proper, both figurative and abstract, requires the viewer to have, above all, artistic competence (Matuchniak-Krasuska 1988). Grotesque art, especially social satire, including caricature, 
additionally requires life competences and awareness of the context of time and place, otherwise it is perceived only as deformation. Jerzy Duda-Gracz's grotesque was understandable to connoisseurs who were able to appreciate his references to the classics (P. Breughel, E. Manet, J. Chełmoński, W. Kowarski), but it was also understandable to "ordinary viewers" who were familiar with the Polish realities (Matuchniak-Krasuska 1999). Likewise, feminist art or women's art requires artistic competence and knowledge of women's situation and their emancipatory aspirations.

A similar rule applies to historical art, including films about the history of World War II. This has been demonstrated by the preliminary pilot study of film reception focused on Munk's Eroica, as discussed below. The study illustrated the perceptual procedures employed by various categories of viewers (Matuchniak-Mystkowska 2019, unpublished data).

Contemporary audiences include professionals (artists, critics, filmmakers), who have artistic competence but not necessarily historical competence, and who are not always familiar with the realities of POW camps described in historical and biographical sources. Ordinary viewers usually lack knowledge about filmmaking or the history of World War II, including the history of POW camps (this topic is omitted in school textbooks). Both these categories of viewers, albeit very different, may also lack sensitivity to these issues, and also lack an understanding and empathy for a different social world.

Sociology students are generally unfamiliar with either the connotations or the referents of the term "oflag", and they also lack historical competence. This entails their lack of understanding of the content of this film about Polish POWs, which was intended to be ironic.

Cinematology students, equipped with knowledge about film (artistic competence), also lack historical knowledge, especially because film appears to be an all-powerful medium that provides knowledge about everything rather than interpretations of past or present events. Those students focus on the analysis of cinematic works, including their formal and structural elements. Nevertheless, even without sufficient historical knowledge, let alone sentimental feelings about Polish POWs (something that characterises the author of this text), they do sense the strange ambiance of Eroica intended by its author. The ability to recognise absurdity, frequently used in art, is another indicator of artistic competence. The hypothesis about the role of artistic competence of the creator and of professional audiences (critics, film theorists) and their prevalent focus on the iconological layer and the different senses of the film (the ironic-grotesque vision of Poles, Polish fates and Polish heroes, the senselessness and tragedy of war, attitudes towards evil...) is confirmed in the empirical material.

This is illustrated by the statements quoted verbatim below:

I saw Eroica and, as someone unfamiliar with the war theme (my knowledge about it comes from films), I believe that the film still does have a powerful impact. I feel emotionally closer to the second part because of the deep psychology of Żak as a character and the legendary fugitive 
Zawistowski, who is in hiding. The first part has more irony, which puts me at a distance from the events presented there. However, if we look at it from an intellectual angle, war can be seen as an absurdity where a drunken man has a chance of survival and where nothing is certain. Without knowing the historical facts, I cannot judge the truthfulness, but I can feel that most of the scenes are true. After the last class with you about oflags, I felt that the second part was very true to the facts, i.e. theatre plays, food distribution, claustrophobia, while the director was commenting on that reality. Thanks to both parts, the one about anti-heroes and the one about heroes, the story of Poland's martyrdom takes on a human rather than a monumental dimension, which is why it speaks to me today.

As I was watching Eroica after so many years, my attention was drawn to Jan Krenz's music. I think it is one of the key elements that add lightness to the film and help us smoothly embrace the convention proposed by Andrzej Munk. The music very consciously influences the viewer's emotions, directing them towards comedy. This is very noticeable in the first part of the film. In the second part, the comedy aspects evoked by the music become more complex and ambiguous. This is particularly noticeable in the final scene where Żak leaves the barracks and walks to the square. The music wavers between being very light and exerting strong emotional pressure. As other men run after him down the stairs to the ground floor of the barrack, the music corresponds to the noise that chased Żak out of his hideout upstairs. When Żak goes out into the square and the others stay behind, the music begins to play a different role. The increasing sound of the drumstick hitting a snare drum, like in a circus before someone jumps through a burning hoop, winds up emotions, making viewers very worried about the protagonist's fate. I think that this simple, well-familiar element of circus music subliminally makes the viewers very worried about the main character. The increasing intensity of the drumstick sound continues, but there is no quick accumulation of events. The music becomes oppressive. When the witnesses' faces fill with horror, we hear the aphonic sounds of the piano, used earlier in the film to emphasise Żak's irritation. When the shot is fired and the main character dies, the music clearly emphasises the loss and the gravity of the situation. I think that Andrzej Munk worked very consciously on the musical layer of the film. The sounds composed by Krenz complete the film, discreetly giving it a multidimensional character.

The audiences who watched the film in the 1950 s, i.e. the period when the film was made, had been participants of World War II, and some of them had the experience of being POWs. The author of the screenplay, Jerzy Stefan Stawiński, and the actor Kazimierz Rudzki, combined artistic and reallife competences. Second Lieutenant Marek Sadzewicz, a prisoner of Oflag II B Arnswalde and II D Gross Born, and the author of excellent memoirs of historical and sociological value, wrote a harsh criticism of Munk's film. 'Let me just mention, for example, Eroica, a lampoon of a film, where the incredible yet authentic story of a man, wanted by the Gestapo and hiding in an oflag, is presented as an inapt mystification to create a legend about someone who had managed to escape from the camp. There was no need to create such legends. Polish prisoners of war can boast the largest number of escapes, where they demonstrated courage, ingenuity, and excellent technical preparation. Each of us, former prisoners of war, remembers individual facts as well as the names of colleagues who died on those occasions. [...] The escapes of British and other prisoners of war have been immortalised in thrillers. For our part, we only have Eroica" (Sadzewicz 1977: 15). 
Contemporary viewers, capable of proper perception of Eroica ("adequate concretisation" in R. Ingarden's terminology) have a complex set of life competences (historical, sociological and biographical knowledge about oflags), which allows them to perceive the iconographic layer. The film is not the only source of knowledge about the situation of POWs. This enables the viewers to analyse each layer of the work: preiconographic, iconographic and iconological, as well as to appreciate its artistic qualities.

This is evidenced by the following statements made by experts specialising in historical and biographical research on POW camps: the historian Prof. Danuta Kisielewicz and Prof. Wiesław Dembek, Chairman of the Former Woldenberg Inmates' Association. These authors also draw attention to the limited educational potential of the film.

In "Eroica. A Heroic Symphony in Two Acts, Kadr Film Group, 1957, directed by Andrzej Munk, screenplay by Jerzy Stawiński, cast: Edward Dziewoński, Kazimierz Rudzki and others" Danuta Kisielewicz provides the following review:

The film consists of two parts: Scherzo alla polacca and Ostinato lugubre. The first part is a story about Dzidziuś Górkiewicz, a participant of the Warsaw Uprising, an ambiguous character who undermines the myth of the heroic insurgent - a patriot. The second one shows the fate of two groups of POWs in German captivity: September 1939 soldiers and 1944 Warsaw insurgents, cultivating the myth of the legendary hero Lieutenant Zawistowski, who allegedly fled from the camp.

The Warsaw insurgents, kindly welcomed by the »September POWs«, form a diverse community. Due to the difficult living conditions in captivity there is no harmony among the POWs, although some Polish officers cultivate the will to fight and preserve the officers' honour. The main character of the second part of the film is Lieutenant Zawistowski, an alleged fugitive from the camp who is hiding in the attic, and who receives medication from his initiated colleagues: a religious man, Marianek, and an intellectual, Turek. Turek (played by Kazimierz Rudzki, himself a former prisoner of the Woldenberg oflag) maintains the myth of the »hero« since it was the duty of an officer in captivity to escape and take up arms. One of the main characters in the film, Lieutenant Żak, decides to escape from the camp, but not because he wants to fight, but because he wants to cut himself off from his other companions: he finds it difficult to live with them in a crowded barrack, surrounded by constant noise. He manages to sneak out of the barrack, helped by other POWs who simulate a scuffle and distract the guard. However, when he is captured and imprisoned in the oflag again, he becomes a man of honour. During an air raid, he goes out to the roll-call square and is shot dead by a guard. Lieutenant Zawistowski sees Żak's death through the window in the attic and commits suicide. Turek successfully asks the German camp crew to take the body away without other prisoners knowing, thus maintaining the legend of Zawistowski's heroic escape.

The film offers an opportunity for viewers to form an opinion about this group of soldiers - victims of war. It shows that POW camps were different from concentration camps. The former were not extermination camps: POWs had better living conditions and were treated better since they were protected by international law, i.e. the Geneva Convention of 1929. This inspires a discussion on the myth of heroism and largely denies Górkiewicz's heroism as well as the »heroism « of the Polish officers - prisoners of war who are shown in the film. If we compare the film with historical truth, we can say that it does not offer a faithful depiction of reality. The 
film is supposedly set in the Murnau oflag (in Bavaria), where about 5,000 Polish officers were held. However, the set does not reconstruct the camp buildings or the interior of the barracks. Also, the film does not faithfully reflect the facts invoked in its plot. Zawistowski represents a prisoner who was actually imprisoned in Murnau, and who pretended to escape and then was hiding from the German camp crew with the help of initiated prisoners because he was accused of murdering some Volksdeutsche. He committed suicide when he saw the Germans approaching, as they noticed the smoke coming out of his hideout. The smoke resulted from a fire caused by the ignition from a primitive cooker made from a tin can. Moreover, one cannot say that Lieutenant Żak was a hero: affected by the »barbed wire disease«, and unable to bear the burden of captivity, he went out to the roll-call square during an air raid and was shot dead. However, the film shows the solidarity of the prisoners who, in order to maintain the morale of other soldiers, continue to sustain the myth of the »heroic « soldier who allegedly escaped from captivity to Britain to fight in the Polish Armed Forces in the West.

The film offers a subjective, fragmentary depiction of the camp realities and does not present all aspects of POW lives: the punishments applied by the German camp crew, officers' conspiratorial undertakings, cultural and educational activities, various forms of friendly help, etc. Instead, it focuses on the psychological and sociological aspect of prisoners' lives in captivity.

Is the picture painted by the film interesting enough to attract viewers? Well, not really. The message is difficult to understand, especially for young viewers who have no knowledge of the fates of Polish POWs in German captivity during World War II. The first part of the film, about Górkiewicz's involvement in the Warsaw Uprising, is more understandable because this historical event is present in academic literature, memoirs and films. In Eroica, the first part is spectacular and interesting, with a comedy-like atmosphere at times, whereas the second part is serious, depressing and gloomy. The film is not strictly exploratory or educational, and it does not put an end to the discussions about the myth of national heroism. While it polemicises with the myth of the heroic Warsaw insurgent, it also shows a picture of Polish POWs and their behaviours which are far from heroic. Rather, their deeds are driven by their patriotic attitudes, adopted and pursued throughout their lives, and by the obligation to fulfil the duties of a soldier (Prof. Danuta Kisielewicz).

\section{Wiesław Dembek, Chairman of the Former Woldenbeg Inmates’ Association, offers the following opinion on Ostinato lugubre, the second part of Eroica, a 1957 film directed by Andrzej Munk:}

This is a very good film, outstanding in terms of the technical mastery manifested in its direction, cinematography and the actors' performances. The film takes on board many of the oflag realities. This knowledge certainly came from the screenplay author Jerzy Stefan Stawiński, and probably also from one of the starring actors, Kazimierz Rudzki. Both had been held in oflags, except that J.S. Stawiński was sent to the camp only after the Warsaw Uprising, so he could not have known the whole evolution of misery and the moods among the prisoners who survived six years in captivity.

What raises objections is the overall historical context of the film, clearly intended as a demythologising work in the absence of the relevant myth in the society. At that time, the communist authorities in Poland took great care to ensure that neither the myth, nor even the slightest piece of information about the oflags and pre-war »Sanation « officers could reach the general public. Former POWs became objects of surveillance, persecution and discrimination only a few years earlier. In this situation, the authors of the film focused almost exclusively on the pathologies of POW lives, resulting from the overcrowded conditions and many years of isolation, thus creating a satirical film which had no counterbalance in other cinematic works that would show the 
enormous creative achievements of the POWs. In fact, Oflag II C Woldenberg was called »the largest Polish school« during the Nazi occupation period. This, combined with the satirical image of the oflag created by the same authors in Zezowate szczęście [Bad Luck], doomed the viewers to a one-sided and false picture of oflag realities, which fitted very well with the propaganda and educational policies of the communist authorities at the time. Unfortunately, the topic of oflags was not taken up by filmmakers in later years, and the resulting books about oflags did not have enough appeal for a wide audience. In this situation, one fears that the vision created by Munk and Stawiński still exists in the minds of the wider public (Prof. Wiesław Dembek).

\section{Conclusion}

Munk's Eroica is one of the first post-war historical adaptations, and is the best-known and most widely-discussed by film experts. Also, it is undoubtedly part of the "Polish Film School" canon. Moreover, the story depicted in the film happened in real life, was reported by the participants of these events and studied by historians. Few other works of art received that much intellectual backup. This twofold argumentation (artistic and historical) justifies the choice of this film and enables sociological analyses of "the truth of time" and "the truth of the screen". The research experiment outlined here covers all the elements of the communication system: the creator, the work and the audience, in a changing historical and generational context, in a manner consistent with the principles of sociology of art. The deliberations presented here are intended only as an introduction to a broader study of the reception of historical films among diverse audiences, a task more suitable for a sociologist than a cinematologist.

As regards the cultivation of social memory, it is important to look at the reception of a film about the difficult and tragic events of World War II on the 80th anniversary of its outbreak: is it perceived as a true, realistic, patriotic and informative picture that glorifies heroism, or as an ironic and grotesque image of anti-heroes? Andrzej Munk, an outstanding film director, most likely did not learn respect for the Polish uniform in his parents' home. His films, made in the 1950s, were interesting from an artistic point of view but his "truth of time" is more aligned with communist ideology than with the actual truth of wartime. Manipulation, still common in films and propaganda, consists in using a rhetorical figure of pars pro toto metonymy, i.e. presenting part of the truth as the whole truth. An incompetent audience is helpless and "falls prey" to art. Several original photographs from Oflag VII A Murnau, taken from Danuta Kisielewicz's book Niewola w cieniu Alp. Oflag VII A Murnau [Captivity in the Shadow of the Alps. Oflag VII A Murnau], which "match" the frames from Eroica, are also part of the truth.

Marek Sadzewicz, an officer and a prisoner of war who authored books about oflags, was aware of the difficulties associated with the subject he was tackling. "Anyone who writes about oflags risks ending up at one of the two extremes. One of them is a sugary idyllic picture with an amateur theatre, an orchestra and U.S. aid parcels. That would be a false image. Another extreme, a picture from a macabre 
play, would be equally false. [...] I do realise the imperfections of my work, and that I will necessarily omit many facts and people. But I would rather do what is possible than remain silent" (Sadzewicz 1977: 15, 16). In my own work, I subscribe to the same idea.

\section{Bibliography}

Baticle Y. (1985), Clés et codes de l'image: l'image numérisée, le vidéo, le cinéma, Magnard, Paris. Bednorz R. (1989), Aby mogli przetrwać. Pomoc dla polskich jeńców wojennych w niewoli Wehrmachtu 1939-1945, Centralne Muzeum Jeńców Wojennych w Łambinowicach-Opolu, Opole.

Bohatkiewicz J. (1971), Oflag II C Woldenberg, Książka i Wiedza, Warszawa.

Brandys M. (1955), Wyprawa do oflagu, Państwowy Instytut Wydawniczy, Warszawa.

Brzezicki F. (2013), W oflagu VII A Murnau. Dziennik polskiego oficera, Centralne Muzeum Jeńców Wojennych w Łambinowicach-Opolu, Opole.

Chateau D. (2006), Esthétique du cinéma, Armand Colin, Paris.

Ethis E. (2011), Sociologie du cinéma et de ses publics, Armand Colin, Paris.

Francastel P. (1984), Problèmes de la sociologie de l'art, [in:] G. Gurvitch (ed.), Traité de sociologie, vol. II, no. 3, Presses Universitaires de France, Paris.

Fularski J. (2009), Wedtug gwiazd na wschód. Moja ucieczka z oflagu i inne przeżycia, W. Wróblewski, (ed.), Drukarnia-Międzychód, Międzychód.

Giziński S., Szutowicz A. (2013), Oflag II B Arnswalde. Jenieckie losy, Wydawnictwo Nortom, Wrocław. Gruszka T.K. (1994), W Murnau, Caldra House, Hove.

Hendrykowski M. (2011a), Eroica, Wydawnictwo Uniwersytetu im. Adama Mickiewicza, Poznań. Hendrykowski M. (2011b), Andrzej Munk, Wydawnictwo Uniwersytetu im. Adama Mickiewicza, Poznań. Honka N. (1998), Życie religijne żołnierzy polskich $w$ niewoli niemieckiej i radzieckiej podczas II wojny światowej, Centralne Muzeum Jeńców Wojennych w Łambinowicach-Opolu, Opole.

Iwanowski W. (1981), Konspiracja w Oflagu VII A Murnau, "Wojskowy Przegląd Historyczny", no. 4, pp. 175-191.

Kisielewicz D. (1998), Oficerowie polscy $w$ niewoli niemieckiej $w$ czasie II wojny światowej, "Studia i Monografie", no. 254, Uniwersytet Opolski, Centralne Muzeum Jeńców Wojennych w Łambinowicach-Opolu, Opole.

Kisielewicz D. (2015), Niewola w cieniu Alp. Oflag VII A Murnau, Centralne Muzeum Jeńców Wojennych w Łambinowicach-Opolu, Opole.

Kłoskowska A. (1972), Społeczne ramy kultury, Państwowe Wydawnictwo Naukowe, Warszawa. Kłoskowska A. (1983), Socjologia kultury, Państwowe Wydawnictwo Naukowe, Warszawa.

Kłoskowska A., Rokuszewska-Pawełek A. (1990), Symbole i mity literackie w potocznym odbiorze, [in:] A. Kłoskowska (ed.), Oblicza polskości, Uniwersytet Warszawski, Warszawa.

Kobylarz R., Sznotala K. (2010), Wykaz niemieckich obozów jenieckich 1939-1945, Centralne Muzeum Jeńców Wojennych w Łambinowicach-Opolu, Opole.

Kurpiewski P. (2017), Historia na ekranie Polski Ludowej, Wydawnictwo Uniwersytetu Gdańskiego, Gdańsk.

Lewandowska-Pijanowska M., Rezler-Wasielewska V. (2016), Sprawa Mamunowa, "Eambinowicki Rocznik Muzealny”, no. 39. pp. 145-175.

Lewandowski J. (2016), Wspomnienia i relacje, [in:] M. Lewandowska-Pijanowska, V. Rezler-Wasielewska, Sprawa Mamunowa, “Łambinowicki Rocznik Muzealny”, no. 39, pp. 145-175. 
Lewicki W. (ed.) (2007), Dzienniki jenieckie polskich oficerów w niewoli Wehrmachtu, Wydawnictwo Wojciecha Lewickiego, Warszawa.

Majchrowski S. (1970), Za drutami Murnau, Wydawnictwo Ministerstwa Obrony Narodowej, Warszawa.

Matuchniak-Krasuska A. (1988), Gust i kompetencja. Społeczne zróżnicowanie recepcji malarstwa, Wydawnictwo Uniwersytetu Łódzkiego, Łódź.

Matuchniak-Krasuska A. (1999), Publiczność wobec metafory plastycznej. O recepcji groteski Jerzego Dudy-Gracza, Wydawnictwo Uniwersytetu Łódzkiego, Łódź.

Matuchniak-Krasuska A. (2001), O mediacyjnym i autonomicznym charakterze socjologii sztuki, "Przegląd Socjologiczny", vol. 2, pp. 53-81.

Matuchniak-Krasuska A. (2010), Zarys socjologii sztuki Pierre'a Bourdieu, Oficyna Naukowa, Warszawa.

Matuchniak-Krasuska A. (2014), Za drutami oflagów. Studium socjologiczne, Centralne Muzeum Jeńców Wojennych w Łambinowicach-Opolu, Opole.

Matuchniak-Krasuska A. (2016), Za drutami oflagów. Jeniec wojenny 613 X/A, Centralne Muzeum Jeńców Wojennych w Łambinowicach-Opolu, Opole.

Matuchniak-Mystkowska A. (2017), Dylematy pamięci jenieckiej, [in:] V. Rezler-Wasielewska (ed.), O niewoli 70 lat po wojnie. Studia i materiały, Centralne Muzeum Jeńców Wojennych w Łambinowicach-Opolu, Opole.

Matuchniak-Mystkowska A. (2019), Historie jenieckie w filmie (na przykladzie "Eroiki" Andrzeja Munka), unpublished data.

Matuchniak-Mystkowska A., Mystkowski J., Stanek P. (eds.) (2018), Niewola i nadzieja. Korespondencja wojenna Andrzeja i Krystyny Mystkowskich, Centralne Muzeum Jeńców Wojennych w Łambinowicach-Opolu, Opole.

Neterowicz A. (2015), Nora. Wspomnienia podporucznika Alojzego Neterowicza jeńca wojennego Oflagu VII A Murnau więźnia politycznego, "Dziedzictwo" Helena Dobranowicz, Bielsko-Biała.

Olesik J. (1988), Oflag II C, Wydawnictwo Ministerstwa Obrony Narodowej, Warszawa.

Ossowski S. (1966), Dzieła, vol. I, U podstaw estetyki, Państwowe Wydawnictwo Naukowe, Warszawa.

Panofsky E. (1971), Studia z historii sztuki, Państwowy Instytut Wydawniczy, Warszawa.

Pollack J. (1986), Jeńcy polscy w hitlerowskiej niewoli, Wydawnictwo Ministerstwa Obrony Narodowej, Warszawa.

Półchłopek W. (2002), Wychowanie fizyczne i sport żolnierzy polskich w obozach jenieckich Wehrmachtu i NKWD (1939-1945), Centralne Muzeum Jeńców Wojennych w Łambinowicach-Opolu, Opole.

Rezler-Wasielewska V. (2001), Działalność naukowo-oświatowa polskich jeńców wojennych w niemieckich i radzieckich obozach podczas II wojny światowej, Centralne Muzeum Jeńców Wojennych w Łambinowicach-Opolu, Opole.

Rowiński J. (2016), Wspomnienia i relacje por. Juliana Rowińskiego, "Lambinowicki Rocznik Muzealny", no. 39, pp. 154-169.

Sadzewicz M. (1977), Oflag II D Gross - Born, Państwowy Instytut Wydawniczy, Warszawa.

Siarkiewicz M. (1998), Murnau. Moje wspomnienia, Kalisz, Archiwum Centralne Muzeum Jeńców Wojennych, Relacje i Wspomnienia, sygn. 942. Some memories available: http://www.info. kalisz.pl/siarkiewicz/index.html (accessed 18.02.2018).

Stawiński J.S. (1984), Opowieści powstańcze. Godzina “W”, Wegrzy, Kanat, Ucieczka, Młodego warszawiaka zapiski z urodzin, Czytelnik, Warszawa.

Steyer K. (2013), II wojna światowa w polskim filmie. Historia a fabuła, Wydawnictwo Muzeum Stutthof, Warszawa-Sztutowo.

Sułkowski B. (1972), Powieść i czytelnicy. Spoleczne warunkowanie zjawisk odbioru, Państwowe Wydawnictwo Naukowe, Warszawa. 
Sułkowski B. (1993), Hamletyzowanie nasze, Wydawnictwo Uniwersytetu Łódzkiego, Łódź.

Wallis M. (1983), O tytułach dzieł sztuki, [in:] M. Wallis, Sztuki i znaki: pisma semiotyczne, Państwowy Instytut Wydawniczy, Warszawa.

Wańkowicz M. (1955), Droga do Urzędowa, Roy Publishers, New York.

Wańkowicz M. (1969), Spod gilotyny, [in:] M. Wańkowicz, Od Stotpców po Kair, Państwowy Instytut Wydawniczy, Warszawa, pp. 433-469.

Wejbert-Wąsiewicz E. (2017a), Bez retuszu czy po liftingu? Obrazy starości i aborcji w filmie, Wydawnictwo Uniwersytetu Łódzkiego, Łódź.

Wejbert-Wąsiewicz E. (2017b), Filmy o wojnie, unpublished report.

Wiktorski P. (1980), Czas biegnie obok, Wydawnictwo Ministerstwa Obrony Narodowej, Warszawa. Zimnica-Kuzioła E. (2003), Światła na widownię. Socjologiczne studium publiczności teatralnej, Wydawnictwo Uniwersytetu Łódzkiego, Łódź.

\title{
Anna Matuchniak-Mystkowska
}

\section{HISTORIE JEŃCÓW WOJENNYCH W FILMACH (PRZYPADEK EROIKI ANDRZEJA MUNKA)}

\begin{abstract}
Abstrakt. W artykule przeanalizowano polskie filmy fabularne poruszające tematykę obozów jenieckich w czasie II wojny światowej, zwłaszcza tzw. Oflagów (niem. Offizierslager), czyli obozów Wehrmachtu dla oficerów. W Polsce w latach 1945-1999 nakręcono blisko 200 filmów fabularnych o II wojnie światowej i okupacji hitlerowskiej, a tylko osiem poruszyło temat obozów jenieckich. Eroica w reżyserii Andrzeja Munka to jeden z pierwszych przykładów i najbardziej znany. Przedstawia społeczny świat oflagów w groteskowym i ironicznym świetle, docenionym przez filmoznawców, ale skrytykowanym przez historyków. Podejście teoretyczne i metodologiczne stosowane w socjologii sztuki i socjologii historycznej może posłużyć do analizy wszystkich elementów systemu komunikacji: twórcy, dzieła i odbiorcy w ich kontekście społecznym i historycznym. Przedstawiona tutaj analiza socjologiczna dotyczy jedynie treści filmu (zestawienie „prawdy czasu” i ,prawdy ekranu”) i jego społecznego odbioru wśród różnych kategorii widzów, z których każdy posiada określone kompetencje. Wykorzystuje się tu koncepcje teoretyczne opracowane przez S. Ossowskiego, A. Kłoskowską, P. Francastela, E. Panofsky'ego i P. Bourdieu, obok analiz historyczno-socjologicznych obozów jenieckich (D. Kisielewicz, A. Matuchniak-Mystkowska). W artykule przedstawiono pewną ideę badawczą i opisano metody, które można wykorzystać do jej realizacji.
\end{abstract}

Słowa kluczowe: Eroica, film polski, recepcja filmowa, II wojna światowa, jeńcy wojenni, oflagi, socjologia historyczna, socjologia filmu, socjologia sztuki. 